\title{
Motion Graphic untuk Pengenalan Warna Dalam Bahasa Inggris
}

\author{
Arta Uly Siahaan*, Heny Anggraini Putri*, Afdhol Dzikri** \\ *Politeknik Negeri Batam, Batam, Indonesia \\ Program Studi Teknik Multimedia dan Jaringan \\ **Politeknik Negeri Batam, Batam, Indonesia \\ Program Studi Teknik Informatika \\ Jalan Ahmad Yani No.1 Batam, Indonesia \\ E-mail: artauly@polibatam.ac.id, hennyanggraini09@gmail.com, afdhol@polibatam.ac.id
}

\begin{abstract}
Abstrak
Salah satu tingkatan pendidikan bagi anak usia dini adalah Taman kanak-kanak. Kehadiran dan perkembangan teknologi memberikan pengaruh yang cukup besar terhadap perkembangan media pembelajaran yang memanfaatkan media berbasis video. Penggunaan video sebagai media pembelajaran pengenalan warna dalam Bahasa Inggris di Taman Kanak-kanak diharapkan bertujuan untuk meningkatkan kualitas sistem pengajaran dan pemahaman anak. Tujuan penelitian ini adalah mengembangkan membuat media pembelajaran mengenal warna dalam Bahasa Inggris melalui implementasi motion graphic dan menyampaikan materi tentang warna dalam Bahasa Inggris melalui media pembelajaran dalam bentuk motion graphic yang sudah dibuat. Produk ini dikembangkan dengan metode Luther sutopo dan didistribusikan kepada Taman kanak-kanak Islam Ibnu Khaldun. Sebelumnya telah dilakukan pengujian di mana ditemukan bahwa media ini sangat bagus untuk digunakan dan terbukti nilai rata-rata siswa mengalami peningkatan dengan belajar menggunakan media ini.
\end{abstract}

Kata kunci: Media edukasi, motion graphic, belajar warna untuk anak TK

\begin{abstract}
One of the levels of education for early childhood is Kindergarten. The presence and development of technology has a considerable influence on the development of learning media that utilizes video-based media. The use of video as a medium for learning color recognition in English in Kindergarten is expected to enhance childrens' understanding. The aim of this research was to develop learning media to recognize colors in English through the implementation of motion graphics and to convey material about color in English through learning media in the form of motion graphics that have been made. This product was developed using the Luther Sutopo method and distributed to Ibn Khaldun's Islamic Kindergarten. Previously, a test was conducted where it was found that this media was very good to use and it was proven that the students' average score had increased by learning to use this media
\end{abstract}

Keywords: Education Media, Motion Graphic, Learning colors for kindergarten

\section{Pendahuluan}

Di era globalisasi saat ini, Bahasa Inggris memiliki peran yang cukup penting sebagai bahasa universal. Cakupannya sangat luas dimana yang artinya adalah bahasa yang berlaku untuk semua orang atau untuk seluruh dunia. Hal inilah yang menunjukkan bahwa Bahasa Inggris mempunyai peran yang sangat penting pada era globalisasi saat ini dan untuk kedepannya. Indonesia merupakan salah satu negara di Asia Tenggara, dimana tingkat penguasaan dalam Bahasa Inggris masih tergolong rendah karena memang Bahasa Inggris masih dianggap sebagai
Bahasa asing. Penguasaan Bahasa asing ini cukup penting untuk diperkenalkan sedari usia dini mengingat usia dini adalah golden moment untuk menguasai suatu Bahasa tertentu.

Hernia (2013) menyebutkan bahwa kemampuan mengenal warna merupakan salah satu aspek dari kemampuan kognitif. Kemampuan mengenal warna pada anak usia dini merupakan hal yang sangat penting bagi perkembangan otak anak, karena pengenalan warna pada anak usia dini dapat merangsang indera penglihatan. Selain dapat merangsang indera penglihatan, pengenalan warna juga meningkatkan kreativitas anak dan daya pikir yang berpengaruh pada 
perkembangan intelektual yakni kemampuan mengingat. Oleh sebab itu mengenalkan warna sejak usia dini sangat dianjurkan agar anak dapat membedakan dan mengetahui macam-macam warna dasar dan komplemennya.

Taman Kanak-kanak (TK) adalah salah satu pendidikan formal yang ada di Indonesia yang menyediakan program pembelajaran bagi anak umur 46 tahun yang bertujuan membantu mengembangkan berbagai potensi yang meliputi sosial, emosional, bahasa, moral, agama, kemandirian, kognitif, fisik/motorik dan seni agar anak dapat mempersiapkan diri untuk pendidikan ditingkat selanjutnya (Depdikbud, 2005). Tugas utama dari TK yakni untuk mempersiapkan anak dengan memperkenalkan berbagai pengetahuan, sikap dan perilaku dengan cara yang menyenangkan. Salah satu TK di Batam yang telah berdiri selama lebih dari 24 tahun adalah TK Islam Ibnu Khaldun, Bengkong Laut. TK Islam Ibnu Khaldun merupakan pendidikan yang mengajarkan hal-hal dasar untuk anak usia dini.

Berdasarkan wawancara yang dilakukan di TK Islam Ibnu Khaldun pada tanggal 3 Januari 2018 pukul 10.00 WIB dengan Ibu Ema, salah seorang guru yang mengajar mengatakan bahwa sistem pengajaran mengenai Bahasa Inggris yakni berdasarkan dengan tema yang ditentukan setiap bulannya yang telah disesuaikan dengan kurikulum yang berlaku, contohnya pada bulan Januari tema yang diberlakukan yaitu tentang rekreasi dalam Bahasa Inggris dan pada bulan Februari tema yang diberlakukan yaitu tentang kendaraan dalam Bahasa Inggris. Sistem pengajaran yang diberikan kepada anak-anak masih diajarkan dengan cara manual yaitu dengan menulis di papantulis, menggambar, mewarnai atau dengan cara menunjukkan suatu objek yang sedang dipelajari secara langsung kepada anak-anak. TK Islam Ibnu Khaldun memiliki 72 murid, dimana dari 72 murid tersebut memiliki umur rata-rata 5-6 tahun. Disana terdapat 5 kelas dan disetiap kelas tersebut mempunyai jumlah murid sebanyak 18 anak. Untuk meningkatkan kualitas belajar dan pemahaman anak mengenai pelajaran Bahasa Inggris terutama untuk mengenal warna di TK Islam Ibnu Khaldun, maka diperlukan media pembelajaran yang menarik dan menyenangkan agar mudah dipahami yaitu dengan membuat media pembelajaran.

Berdasarkan pembahasan yang sudah diuraikan, maka dikembangkan sebuah media pembelajaran berbasis Motion Graphic. Motion Graphic memadukan beberapa unsur multimedia berupa audio, gambar dan tulisan, dimana video yang dihasilkan tersebut akan lebih fleksibel, menarik dan dalam informasi yang disampaikan dianggap lebih komunikatif. Pembelajaran tentang mengenal warna dalam Bahasa Inggris untuk anak TK Islam Ibnu Khaldun akan lebih menarik jika disampaikan melalui konten gambar yang bergerak serta diiringi dengan audio. Maka dalam penyusunan tugas akhir ini penulis mengambil judul "Mengenal Warna Dalam Bahasa Inggris Berbasis Motion Graphic Untuk Anak TK.

Adapun yang menjadi tujuan penelitian ini adalah membuat media pembelajaran mengenal warna dalam Bahasa Inggris melalui implementasi motion graphic dan menyampaikan materi tentang warna dalam Bahasa Inggris melalui media pembelajaran dalam bentuk motion graphic yang sudah dibuat. Penelitian ini diharapkan bermanfaat untuk sebagai media pembelajaran bagi anak TK dan dapat dimanfaatkan oleh guru dan anak dalam menyampaikan dan memahami materi mengenai warna dalam Bahasa Inggris, secara khusus media pembelajaran ini dibuat untuk TK Islam Ibnu Khaldun. Sedangkan manfaat teoritisnya adalah penelitian ini akan bermanfaat sebagai bahan referensi untuk penelitian selanjutnya.

\section{LANDASAN TEORI}

\subsection{Tinjauan Pustaka}

Penelitian tentang pengembangan aplikasi pembelajaran dibuat oleh Marlin, dkk (2012) dari Fakultas Ilmu Komputer Universitas Gunadarma dengan judul "Aplikasi Pengenalan Dasar-dasar Bahasa Inggris Untuk Anak Usia Dini Menggunakan Adobe Flash CS3 Professional". Penelitian tersebut bertujuan untuk mengetahui efektifitas dari media aplikasi pembelajaran aplikasi pada anak usia dini dengan materi pengenalan dasar Bahasa Inggris. Hasil penelitian yang dibuat yakni memberikan alternatif bagi kalangan pengajar maupun orang tua dalam mengajarkan membaca khususnya mengenal huruf dalam suatu media belajar yang lebih interaktif dan dapat menarik perhatian anak.

Penelitian pemanfaatan Software Macromedia Flash dilakukan oleh Siroj (2010) yang berjudul "Pemanfaatan Software Macromedia Flash Sebagai Media Pembelajaran Bahasa Inggris Anak Usia Dini" di Prodi Pendidikan Bahasa Indonesia Program Pascasarjana Universitas Negeri Semarang. Berdasarkan hasil yang disimpulkan bahwa Software Macromedia Flash dapat dimanfaatkan sebagai media pembelajaran Bahasa Inggris untuk anak usia dini. Selain itu, pembelajaran Bahasa Inggris anak usia dini dengan memanfaatkan Software Macromedia Flash sebagai media pembelajaran dapat dilakukan dengan baik oleh guru TK, Playgroup maupun orang tua anak. Selain Bahasa Inggris, Software Macromedia Flash sangat mungkin dikembangkan dalam pembelajaran bahasa lainnya.

Penelitian selanjutnya dilakukan oleh Saurina (2016) dari Fakultas Teknik Universitas Wijaya Kusuma Surabaya dengan judul "Pengembangan Media Pembelajaran Untuk Anak Usia Dini Menggunakan Augmented Reality". Hasil uji coba menjelaskan bahwa 93\% anak dapat mengenali objek binatang dari lingkungan hidupnya, sebesar $100 \%$ menyatakan anak dapat mengulang ejaan nama dari hewan dalam Bahasa Indonesia yang diperagakan 
dengan augmented reality, sebesar 95\% anak dapat mengulang ejaan nama dari hewan dengan Bahasa Inggris yang diperagakan dengan $A R$, sebesar 95\% anak dapat menyebutkan ciri-ciri binatang dengan memilih salah satu bagian tubuh dari binatang yang dipilih dan sebesar 100\% menyatakan anak lebih tertarik menggunakan $A R$ daripada menggunakan Alat Peraga Edukasi (APE) sebagai media pembelajaran.

Penelitian selanjutnya dilakukan oleh Fitriyani, dkk (2014) yang berjudul "Pengembangan Aplikasi Pengenalan Huruf, Angka Dan Warna Untuk Anak Usia Dini Berbasis Android" di Sekolah Tinggi Teknologi Garut. Dari hasil penelitian yang dilakukan menyatakan bahwa aplikasi pengenalan huruf, angka dan warna telah berfungsi dengan baik dan sesuai dengan tujuan yaitu mengembangkan aplikasi media pembelajaran yang menarik dan mempermudah dalam mengingat huruf, angka dan warna.

Selanjutnya, penelitian dilakukan oleh Purwanti, dkk (2015) dengan judul "Pengembangan Motion Graphic Pembelajaran Mata Pelajaran Pendidikan Kewarganegaraan Kelas I Sekolah Dasar" dari Fakultas Ilmu Pendidikan UNY. Hasil dari penelitian yang dilakukan menyatakan bahwa video dapat diterima oleh murid maupun guru karena materi yang diajarkan lebih menyenangkan dan mudah dipahami, sehingga dapat meningkatkan aspek kognitif pada murid.

Adapun perbedaan pada Tabel I menjelaskan mengenai perbandingan yang terdapat pada penelitian sebelumnya dengan penelitian yang akan penulis buat.

TABEL I

TINJAUAN PUSTAKA

\begin{tabular}{|c|c|c|c|c|}
\hline No & $\begin{array}{l}\text { Pengaran } \\
\text { g (Tahun) }\end{array}$ & Judul & Produk & Hasil \\
\hline 1. & $\begin{array}{l}\text { Alfa } \\
\text { Marlin, } \\
\text { Siti } \\
\text { Andini, } \\
\text { Sri } \\
\text { Wahyuni } \\
(2012) \text {. }\end{array}$ & $\begin{array}{l}\text { Aplikasi } \\
\text { Pengenalan } \\
\text { Dasar- } \\
\text { Dasar } \\
\text { Bahasa } \\
\text { Inggris } \\
\text { Untuk Anak } \\
\text { Usia Dini } \\
\text { Menggunak } \\
\text { an Adobe } \\
\text { Flash CS3 } \\
\text { Professiona } \\
\text { 1. }\end{array}$ & $\begin{array}{l}\text { Membuat } \\
\text { aplikasi } \\
\text { pengenalan } \\
\text { Bahasa Inggris } \\
\text { dasar untuk } \\
\text { anak usia dini } \\
\text { dengan gambar, } \\
\text { animasi, dan } \\
\text { suara yang } \\
\text { menarik dapat } \\
\text { membuat } \\
\text { seorang anak } \\
\text { lebih tertarik } \\
\text { untuk belajar. }\end{array}$ & $\begin{array}{l}\text { Pengujian } \\
\text { efektifitas } \\
\text { video } \\
\text { diterima } \\
\text { dengan baik, } \\
\text { karena } \\
\text { aplikasi ini } \\
\text { terdapat } \\
\text { tampilan } \\
\text { yang hidup } \\
\text { dengan } \\
\text { gambar- } \\
\text { gambar yang } \\
\text { dapat } \\
\text { ditampilkan } \\
\text { dengan jelas. }\end{array}$ \\
\hline 2. & $\begin{array}{l}\text { Badrus } \\
\text { Siroj } \\
(2010) .\end{array}$ & $\begin{array}{l}\text { Pemanfaata } \\
\text { n Software } \\
\text { Macromedi } \\
\text { a Flash } \\
\text { Sebagai } \\
\text { Media } \\
\text { Pembelajar } \\
\text { an Bahasa } \\
\text { Inggris } \\
\text { Anak Usia } \\
\text { Dini. }\end{array}$ & $\begin{array}{l}\text { memanfaatkan } \\
\text { Software } \\
\text { Macromedia } \\
\text { Flash dalam } \\
\text { pembelajaran } \\
\text { sebagai media } \\
\text { pembelajaran } \\
\text { Bahasa Inggris } \\
\text { anak usia dini. }\end{array}$ & $\begin{array}{l}\text { Media } \\
\text { pembelajara } \\
\mathrm{n} \\
\text { menggunaka } \\
\mathrm{n} \quad \text { Software } \\
\text { Macromedia } \\
\text { Flash dapat } \\
\text { dilakukan } \\
\text { dengan baik } \\
\text { oleh guru } \\
\text { TK, } \\
\text { Playgroup } \\
\text { maupun oleh }\end{array}$ \\
\hline
\end{tabular}

\begin{tabular}{|c|c|c|c|c|}
\hline & & & & $\begin{array}{l}\text { orang tua } \\
\text { anak. }\end{array}$ \\
\hline 3. & $\begin{array}{l}\text { Nia } \\
\text { Saurina } \\
(2016)\end{array}$ & $\begin{array}{l}\text { Pengemban } \\
\text { gan Media } \\
\text { Pembelajar } \\
\text { an Untuk } \\
\text { Anak Usia } \\
\text { Dini } \\
\text { Menggunak } \\
\text { an } \\
\text { Augmented } \\
\text { Reality }\end{array}$ & $\begin{array}{l}\text { Mengembangk } \\
\text { an media } \\
\text { pembelajaran } \\
\text { yang digunakan } \\
\text { untuk } \\
\text { mengenalkan } \\
\text { binatang } \\
\text { kepada anak } \\
\text { usia dini. }\end{array}$ & $\begin{array}{l}93 \% \text { anak } \\
\text { dapat } \\
\text { mengenali } \\
\text { objek } \\
\text { binatang dari } \\
\text { lingkungan } \\
\text { hidupnya, } \\
95 \% \text { anak } \\
\text { dapat } \\
\text { mengulang } \\
\text { ejaan nama } \\
\text { dari hewan } \\
\text { dengan } \\
\text { Bahasa } \\
\text { Inggris. }\end{array}$ \\
\hline 4. & $\begin{array}{l}\text { Nurul } \\
\text { Fitriyani, } \\
\text { dkk } \\
(2014)\end{array}$ & $\begin{array}{l}\text { Pengemban } \\
\text { gan } \\
\text { Aplikasi } \\
\text { Pengenalan } \\
\text { Huruf, } \\
\text { Angka dan } \\
\text { Warna } \\
\text { Untuk Anak } \\
\text { Usia Dini } \\
\text { Berbasis } \\
\text { Android }\end{array}$ & $\begin{array}{l}\text { Mengembangk } \\
\text { an aplikasi } \\
\text { media } \\
\text { pembelajaran } \\
\text { yang menarik } \\
\text { dan } \\
\text { mempermudah } \\
\text { dalam } \\
\text { mengingat } \\
\text { huruf, angka } \\
\text { dan warna. }\end{array}$ & $\begin{array}{l}\text { Media } \\
\text { pembelajara } \\
\mathrm{n} \text { berbasis } \\
\text { android yang } \\
\text { memiliki } \\
\text { fitur dua } \\
\text { bahasa yaitu } \\
\text { Bahasa } \\
\text { Indonesia } \\
\text { dan Bahasa } \\
\text { Inggris untuk } \\
\text { melengkapi } \\
\text { penelitian } \\
\text { sebelumnya. }\end{array}$ \\
\hline 5. & $\begin{array}{l}\text { Purwanti } \\
\text { 'Haryanto } \\
\text { (2015). }\end{array}$ & $\begin{array}{l}\text { Pengemban } \\
\text { gan Motion } \\
\text { Graphic } \\
\text { Pembelajar } \\
\text { an Mata } \\
\text { Pelajaran } \\
\text { Pendidikan } \\
\text { Kewargane } \\
\text { garaan } \\
\text { Kelas I } \\
\text { Sekolah } \\
\text { Dasar. }\end{array}$ & $\begin{array}{l}\text { Menghasilkan } \\
\text { motion graphic } \\
\text { untuk mata } \\
\text { pelajaran } \\
\text { Kewarganegara } \\
\text { an pada kelas 1 } \\
\text { Sekolah Dasar } \\
\text { yang layak } \\
\text { dijadikan } \\
\text { sebagai sumber } \\
\text { belajar. }\end{array}$ & $\begin{array}{l}\text { Produk } \\
\text { media } \\
\text { pembelajara } \\
\mathrm{n} \text { motion } \\
\text { graphic } \\
\text { mampu } \\
\text { meningkatka } \\
\mathrm{n} \\
\text { keterampilan } \\
\text { berpikir } \\
\text { kritis siswa } \\
\text { pada materi } \\
\text { pokok yang } \\
\text { berbeda. }\end{array}$ \\
\hline 6. & $\begin{array}{l}\text { Heny } \\
\text { Anggrain } \\
\text { i Putri } \\
(2018) .\end{array}$ & $\begin{array}{l}\text { Mengenal } \\
\text { Warna } \\
\text { Dalam } \\
\text { Bahasa } \\
\text { Inggris } \\
\text { Berbasis } \\
\text { Motion } \\
\text { Graphic } \\
\text { Untuk Anak } \\
\text { TK. }\end{array}$ & $\begin{array}{l}\text { Merancang } \\
\text { media } \\
\text { pembelajaran } \\
\text { berbasis Motion } \\
\text { Graphic } \\
\text { tentang } \\
\text { pengenalan } \\
\text { warna } \\
\text { berBahasa } \\
\text { Inggris. }\end{array}$ & $\begin{array}{l}\text { Para guru } \\
\text { terbantu } \\
\text { dengan } \\
\text { adanya video } \\
\text { tersebut dan } \\
\text { anak-anak } \\
\text { mengalami } \\
\text { peningkatan } \\
\text { tentang } \\
\text { warna } \\
\text { setelah } \\
\text { menonton } \\
\text { video. }\end{array}$ \\
\hline
\end{tabular}

Berdasarkan penelitian diatas, maka perbedaan pada penelitian ini yaitu penulis memanfaatkan media pembelajaran berbasis video mengenai pengenalan warna dalam Bahasa Inggris untuk anak TK Islam Ibnu Khaldun yang masih cukup sulit mengerti tentang pembelajaran Bahasa Inggris. Dengan adanya video pembelajaran yang penulis buat, maka audience dapat dengan cepat mengerti pelajaran yang disampaikan karena dibantu oleh gambar yang bergerak, typografi dan audio.

\subsection{Pendidikan Anak Usia Dini (PAUD)}


Jenjang pendidikan dasar dalam upaya pembinaan yang ditujukan bagi anak sejak lahir sampai dengan usia 6 tahun menjadi landasan pendidikan anak usia dini. Menurut Hasan (2009) pada usia ini dilakukan pemberian rangsangan pendidikan untuk membantu pertumbuhan dan perkembangan jasmani dan rohani agar kelak si anak memiliki kesiapan yang cukup dalam memasuki pendidikan jenjang selanjutnya yang diselenggarakan pada jalur formal maupun informal.

\subsection{Warna}

Menurut Junaedi (2003) warna bersifat subjektif karena warna memiliki hubungan yang sangat kuat dengan seseorang yang sedang melihatnya. Warna adalah suatu cahaya yang dipantulkan dari suatu objek ke mata manusia. Hal ini menyebabkan kerucutkerucut warna pada retina bereaksi. Sehingga terjadinya gejala warna pada objek-objek yang dilihat sehingga dapat mengubah persepsi manusia.

\subsection{Motion Graphic}

Fabriansyah (2016) berpendapat bahwa Motion Graphic menggabungkan potongan elemen-elemen desain/animasi dengan berbasiskan pada media visual, elemen yang digabungkan bisa berupa bahasa film dengan desain grafis, dengan memasukkan elemen yang berbeda-beda seperti 2D atau 3D. Motion Graphic juga dapat diartikan sebagai suatu penggabungan seperti animasi 2D dan 3D, ilustrasi, tipografi, fotografi, videografi dan musik dengan menggunakan teknik animasi.

\subsection{Multimedia Pembelajaran}

Menurut Sanaky (2009) media pembelajaran menjadi alat yang memiliki fungsi dalam penyampaian pesan dalam proses pembelajaran. Hal-hal yang dilibatkan dalam pembelajaran adalah komunikasi antar mahasiswa, pengajar dan bahan ajar yang sudah disediakan. Dengan adanya pesan yang tersedia, dan ada media yang baik yang digunakan, maka akan tercapai tujuan yang diharapkan dalam pemberlajarn tersebut. Selain itu, Media video menurut Sukiman (2012) adalah seperangkat komponen atau media yang mampu menampilkan gambar sekaligus suara dalam waktu bersamaan. Tidak semua video yang ada dapat dikategorikan sebagai media pembelajaran. Sangat diperlukan riset dan pengembangan lebih untuk video tersebut untuk menunjang proses pembelajaran.

\subsection{Konsep Animasi}

Animasi merupakan suatu proses penciptaan gerakan yang dibentuk melalui simulasi gerakan yang dibuat dengan memutar serangkaian gambar atau frame. Perekaman animasi dapat dilakukan melalui media analog, seperti buku, film gambar bergerak, rekaman video atau di media digital, termasuk sejumlah format seperti GIF animasi, animasi Flash atau video digital. Menurut Suyanto (2007), animasi ada Sembilan macam, yaitu animasi sel, animasi frame, animasi sprite, animasi lintasan, animasi spline, animasi vector, animasi karakter, animasi computational, dan morphing. Mengimplementasikan video motion grafic tentang mengenal warna dalam bahasa inggris memanfaatkan pergerakan gambar yang bergantian dalam setiap framenya, oleh karena itu jenis animasi yang digunakan dalam penelitian ini adalah animasi frame.

\subsection{Metode Penyelesaian Masalah}

Dalam penelitian ini, penulis menggunakan sebuah metode pengembangan multimedia yaitu metode Luther-Sutopo. Metode ini dipilih karena penelitian ini bertujuan untuk merancang dan menghasilkan motion grafis yang mana dibutuhkan langkah-langkah yang jelas dan lengkap sampai produk ini selesai. Dalam hal ini, penulis melihat bahwa tahapan metode Luther Sutopo sangat sesuai dan tepat untuk mencapai tujuan penelitian. Menurut Sutopo (2003) metodologi pengembangan multimedia terdiri dari enam tahapan, yaitu concept, design, material collecting, assembly, testing dan distribution. Pada Gambar 1, disajikan tentang Tahapan metodologi pengembangan multimedia.

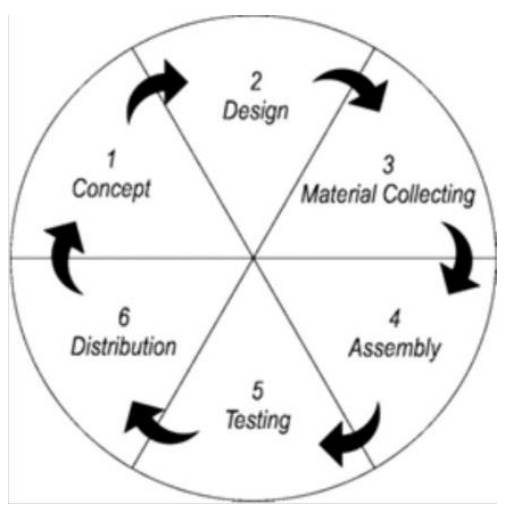

Gambar 1. Tahapan dari metode Luther Sutopo (2003)

1) Concept : Di tahap ini, dilakukan penentuan tujuan, termasuk identifikasi audiens, macammacam aplikasi (presentasi, interaktif dll), tujuan aplikasi (informasi, hiburan, pelatihan dll) dan spesifikasi umum.

2) Design : Peneliti membuat spesifikasi secara rinci mengenai arsitektur proyek, gaya dan kebutuhan material untuk proyek.

3) Material Collecting : Pengumpulan bahan dapat dikerjakan paralel dengan tahap assembly. Pada tahap ini dilakukan pengumpulan bahan seperti image, animasi, audio dll yang diperlukan untuk tahap berikutnya.

4) Assembly : Tahap ini merupakan tahap dimana seluruh objek dibuat, pembuatan aplikasi berdasarkan storyboard atau diagram objek yang berasal dari tahap desain.

5) Testing : Untuk langkah ini dilakukan testing secara modular untuk memastikan apakah hasilnya seperti yang diinginkan atau tidak. 
Menurut Arikunto (2010), angket/kuesioner adalah daftar pertanyaan yang diberikan kepada responden sesuai dengan permintaan pengguna. Dengan demikian angket/kuesioner merupakan daftar pertanyaan yang telah disiapkan oleh peneliti, dimana setiap pertanyaan tersebut berkaitan dengan masalah penelitian. Menurut Zainul dan Nasoetion yang dikutip oleh Suryanto (2008), pretest adalah tes yang diberikan sebelum pembelajaran dimulai, yang bertujuan untuk mengetahui sejauh mana siswa menguasai materi yang diberikan. Sedangkan posttest adalah tes yang diberikan sesudah pembelajaran, tujuannya untuk mengetahui sejauh mana siswa menguasai bahan yang telah diajarkan.

6) Distribution : CD dan aplikasi Youtube menjadi cara yang dilakukan untuk pelaksanaan distribusi dalam penelitian ini.

\subsection{Adobe CS6}

Dalam proses pembuatan video pembelajaran ini, penulis menggunakan beberapa software Adobe yaitu Adobe Illustrator CS6, Adobe After Effect CS6 dan Adobe Premiere CS6.

\section{ANALisis Dan PERANCANGan}

\subsection{Concept}

Video motion graphic yang dikembangkan yaitu video pembelajarangan mengenai warna dalam bahasa Inggris. Video akan ditujukan kepada anak-anak TK Islam Ibnu Khaldun Batam. Video nantinya akan berupa potongan-potongan gambar yang mengajarkan nama warna dan gabungan warna dalam bahasa Inggris. Durasi video adalah 5 menit.

\subsection{Desain}

Setelah merancang konsep, selanjutnya adalah tahap pembuatan desain. Pada tahap ini terdapat perancangan alur cerita, storyboard, audio dan visual. Dalam pembuatan motion graphic ini, dibutuhkan storyboard sebagai tahapan awal dalam penyusunan video motion graphic. Gambar 2-5 merupakan storyboard yang dibuat untuk diterapkan dalam penelitian ini.

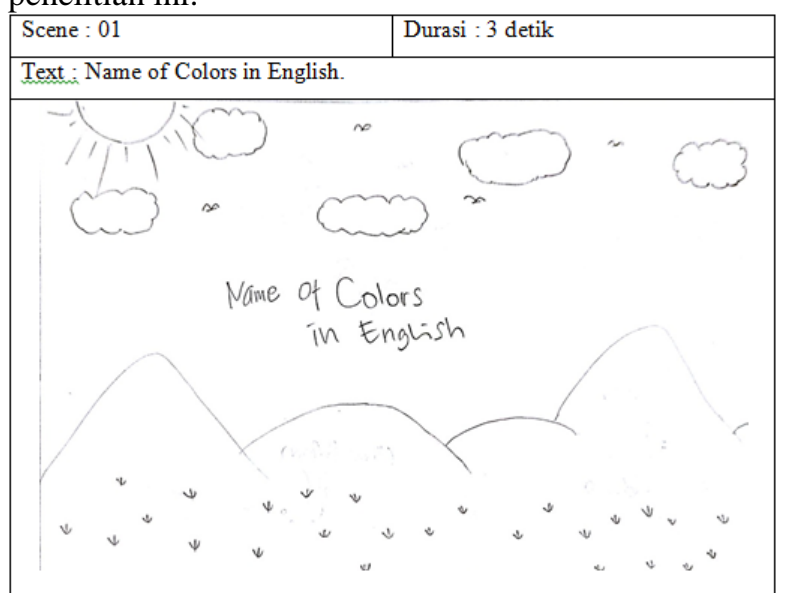

Gambar 2. Storyboard scene 1

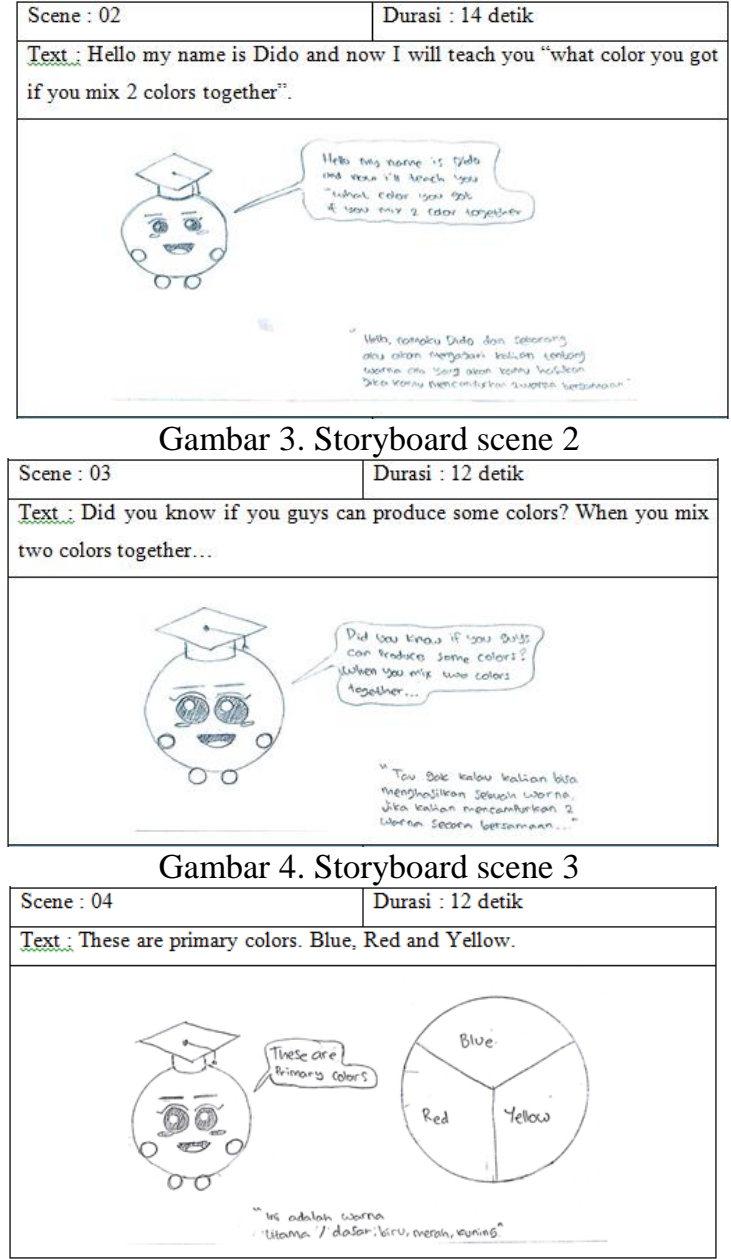

Gambar 5. Storyboard scene 4

Dalam tahap merancang motion graphic tentang warna dalam Bahasa Inggris ini, terdapat karakter bernama Dido yang akan menjelaskan hal-hal terkait warna dan dibutuhkan audio untuk membantu dalam menyampaikan materi yang ada didalam video tersebut. Pada video motion graphic ini akan menggunakan suara dubbing sebagai narasi dan juga terdapat backsound pada video.

3.3 Material Collecting : Tahap ini merupakan proses pengumpulan seluruh bahan yang telah dirancang ditahap sebelumnya. Bahan-bahan tersebut antara lain storyboard dan audio. Hasil pengeditan gambar dan backsound dibutuhkan untuk membuat video motion graphic ini.

3.4 Assembly : Tahap ini adalah tahapan menyusun dan menggabungkan seluruh material yang sudah dikumpulkan pada tahap sebelumnya. Tahap pembuatan video motion graphic ini menggunakan software After Effect CS6 dan Adobe Premiere CS6. Beberapa kegiatan pada tahap ini adalah animasi, editing dan rendering.

Proses animasi ini menggunakan software Adobe After Effects CS6. Proses ini menggabungkan seluruh materi dan objek hingga memberikan efek gerak dan 
terbentuklah motion graphic yang memanfaatkan settingan position, rotation, scale dan efek lainnya.

Selanjutnya proses editing yaitu menggunakan Adobe Premiere CS6 untuk diberi backsound, hasil dubbing dan transisi. Setelah tahap editing sudah selesai dibuat maka proses terakhir adalah rendering. Video motion graphic ini menggunakan Adobe Premiere CS6 untuk melakukan rendering. Rendering bisa dilakukan dengan cara klik menu file $>$ export $>$ media, atau bisa juga dengan cara tekan ctrl $+\mathrm{m}$, kemudian tentukan output yang dihasilkan dan tentukan dimana video akan disimpan.

3.5 Testing : Untuk tahap testing akan menggunakan alpha test dan beta test untuk melihat hasil kelayakan pada video motion graphic ini. Alpha Test : Merupakan pengujian yang fungsional, dimana pengujian ini dilakukan oleh para dosen ahli dan guru sebagai validatornya. Uji validasi ini dilakukan untuk menilai kelayakan pada video motion graphic yang telah dibuat. Gambar 6 menyajikan tahapan pelaksanaan Alpha test.

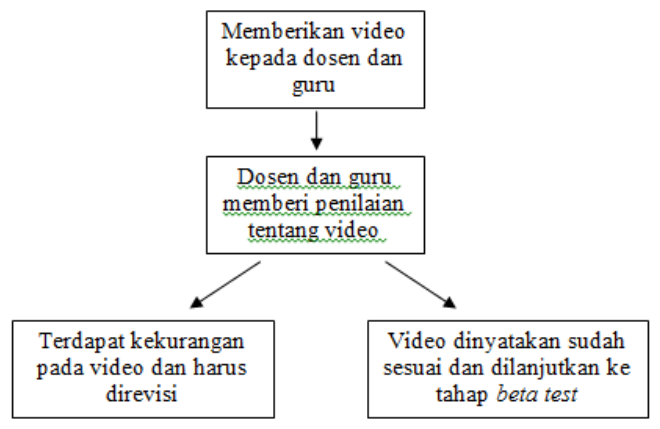

Gambar 6. Tahapan alpha test

Kuesioner ini dilakukan untuk mengevaluasi media pembelajaran sebelum diujicobakan. Kuesioner memiliki 9 butir soal yang berisi tentang aspek-aspek untuk menilai apakah video motion graphic mengenal warna dalam bahasa Inggris yang dibuat ini layak atau tidak. Gambar 7 menunjukkan aspek-aspek dari kuesioner dan Gambar 8 adalah perhitungan indeks \%.

\begin{tabular}{|c|l|}
\hline No. & \multicolumn{1}{|c|}{ Pertanyaan } \\
\hline 1. & $\begin{array}{l}\text { Tampilan video motion graphic Mengenal Wama Dalam Bahasa } \\
\text { Inggris terlihat menarik. }\end{array}$ \\
\hline 2. & $\begin{array}{l}\text { Pemilihan wama (wama pada pertanyaan di video) pada video sudah } \\
\text { sesuai. }\end{array}$ \\
\hline 3. & $\begin{array}{l}\text { Karakter pada video motion graphic Mengenal Wama Dalam } \\
\text { Bahasa Inggris sudah sesuai untuk anak-anak. }\end{array}$ \\
\hline 4. & $\begin{array}{l}\text { Penyampaian suara (dubbing) yang diucapkan sudah sesuai dan } \\
\text { mudah dipahami. }\end{array}$ \\
\hline 5. & $\begin{array}{l}\text { Video motion graphic Mengenal Wama Dalam Bahasa Inggris } \\
\text { mudah dimengerti oleh anak-anak. }\end{array}$ \\
\hline 6. & Video sudah cocok ditayangkan sebagai bahan ajar untuk anak TK. \\
\hline 7. & Durasi video sudah sesuai sebagai bahan ajar untuk anak TK. \\
\hline 8. & $\begin{array}{l}\text { Video mengandung nilai yang dapat menambah pengetahuan anak } \\
\text { tentang wama dalam Bahasa Inggris. }\end{array}$ \\
\hline 9. & $\begin{array}{l}\text { Secara keseluruhan video sudah cocok untuk digunakan sebagai } \\
\text { bahan ajar untuk anak TK. }\end{array}$ \\
\hline
\end{tabular}

Gambar 7. Aspek pertanyaan untuk kuesioner
Setelah soal sudah dibagikan pada validator, selanjutnya melakukan perhitungan terhadap data yang sudah diisi.

- Menghitung indeks \% dari hasil kuesioner :

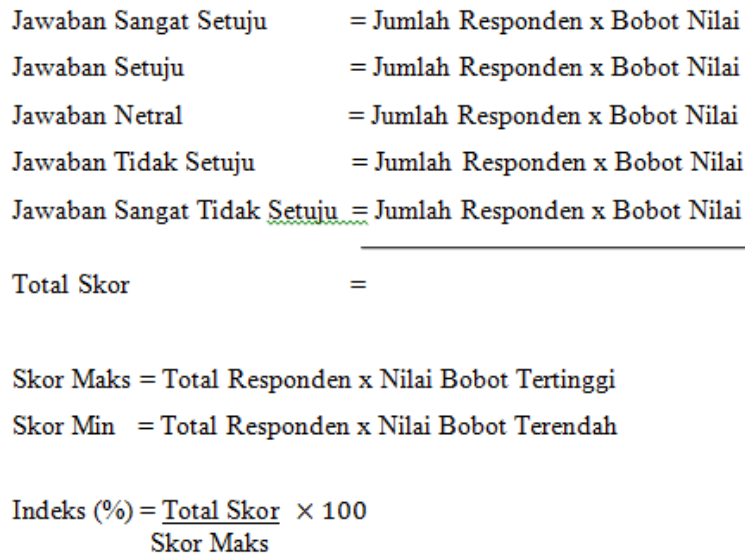

Gambar 8. Perhitungan indeks

Mengubah nilai indeks \% kedalam kriteria kualitatif :

Kurang baik: Apabila indeks kurang dari 49\%

Cukup baik : Apabila indeks mencapai 50\% - 70\%

Baik : Apabila indeks mencapai 71\% - 100\%

Pada kuesioner validasi ahli, bobot skor maksimal adalah 5 sedangkan bobot skor minimum adalah 1 . Setelah mendapatkan kriteria kualitatif yang cukup baik, maka video akan dilanjutkan pada tahap selanjutnya yaitu beta test.

Selanjutnya untuk Beta Test menggunakan desain penelitian one group pretest posttest design dengan satu macam perlakuan, responden yang dilibatkan adalah siswa TK. Terdapat satu kelompok yang dilakukan pada test ini yaitu test awal (pretest) untuk mengukur kondisi awal $\left(\mathrm{O}_{1}\right)$. Kemudian dilakukan eksperimen yang diberi perlakuan (X). Terakhir satu kelompok diberi perlakuan test akhir (posttest) $\left(\mathrm{O}_{2}\right)$. Pengujian eksperimen lakukan seperti pada Tabel II.

TABEL III

PENGUJIAN EKSPERIMEN

\begin{tabular}{|c|c|c|}
\hline Pre-test & Treatment & Post-test \\
\hline $\mathrm{O}_{1}$ & Video media pembelajaran & $\mathrm{O}_{2}$ \\
\hline
\end{tabular}

Hasil pengujian kemudian dihitung untuk mendapatkan hasil rata-rata dengan perhitungan berikut :

$$
\underline{X_{1}}+\underline{X}_{2}+\underline{X}_{3}+\ldots . \underline{X_{n}}=\text { Rata - rata }
$$

Keterangan :

$\mathrm{X}=$ Nilai siswa

$\mathrm{n}=$ Jumlah siswa

Dengan demikian rata-rata yang didapat akan menunjukkan apakah setelah dilakukan test diatas nilai dan tingkat pengetahuan siswa akan meningkat atau 
tidak.

3.6 Distribution : Setelah tidak ada kekurangan pada video tersebut, selanjutnya video akan disimpan dalam media penyimpanan DVD dan diserahkan kepada pihak TK Islam Ibnu Khaldun sebanyak 2 keping DVD sebagai bahan pembelajaran untuk ajaran berikutnya dan akan di upload ke Youtube sebagai bahan pembelajaraan yang bisa digunakan oleh khalayak umum.

\section{HASIL DAN PEMBAHASAN}

\subsection{Hasil Implementasi}

Pada bagian ini menunjukan hasil yang sudah jadi dari rancangan yang dibuat sebelumnya. Pada Tabel III menunjukkan scene dari storyboard dengan tampilan scene output yang sudah selesai dibuat.

TABEL IIIII

HASIL IMPLEMENTASI PRODUK

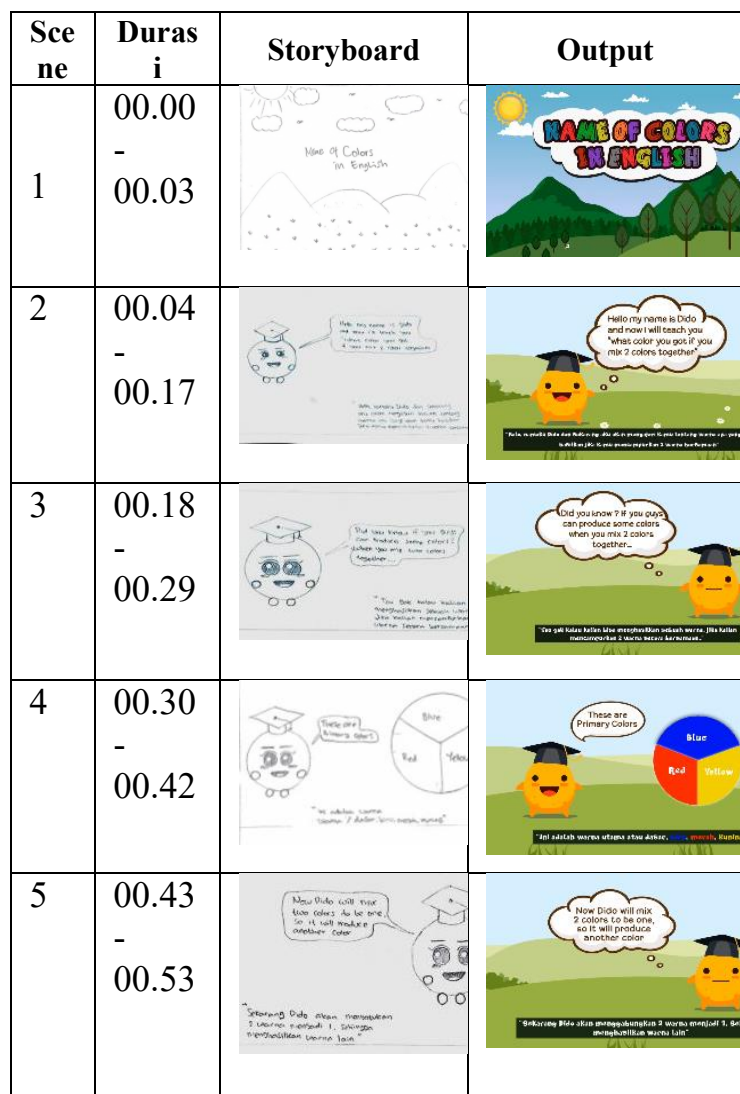

\subsection{Hasil Pengujian}

Pengembangan media pembelajaran ini dilakukan sesuai dengan prosedur alpha test dan beta test dengan menggunakan one group pretest posttest design yang sudah dijelaskan pada bab sebelumnya. Perhitungan validasi menentukan kelayakan video yang telah dibuat.

Uji kelayakan video dilakukan oleh 4 validator ahli, 2 validator dari dosen dan laboran Politeknik Negeri Batam yaitu Pak Afdhol Dzikri dan Pak Ardiman Firmanda, sedangkan 2 validator lainnya adalah guru
TK Islam Ibnu Khaldun yaitu Ibu Nurhayati dan Ibu Saemah. Kriteria untuk dipilih sebagai validator adalah dosen dan laboran yang memahami bidang motion grafis dan untuk validator dari guru TA adalah karena mereka merupakan bagian dari pengembang produk ini, serta memahami dengan baik materi yang menjadi konten dari produk yang dibuat. Selain itu validator juga memberikan masukan seperti memasukkan lagu anak-anak pada video serta membuat karakter lebih menarik lagi. Dari masukan yang diberikan oleh validator, penulis mengganti dari backsound instrumental menjadi backsound lagu anak pada video motion graphic. Analisis data penilaian keseluruhan dari 4 validator dapat dilihat pada Gambar 9.

\begin{tabular}{|c|c|c|c|c|c|c|}
\hline No. & Pertanyaan & $\begin{array}{l}\text { SS } \\
(5)\end{array}$ & $\begin{array}{l}\text { S } \\
(4)\end{array}$ & $\begin{array}{l}\mathrm{N} \\
\text { (3) }\end{array}$ & $\begin{array}{l}\text { TS } \\
(2)\end{array}$ & $\begin{array}{l}\text { STS } \\
\text { (1) }\end{array}$ \\
\hline 1. & $\begin{array}{l}\text { Tampilan video motion graphic Mengenal } \\
\text { Wama Dalam Bahasa Inggris terlihat menarik. }\end{array}$ & 1 & 3 & & & \\
\hline 2. & $\begin{array}{l}\text { Pemilihan wama (wama pada pertanyaan di } \\
\text { video) pada video sudah sesuai. }\end{array}$ & 1 & 3 & & & \\
\hline 3. & $\begin{array}{l}\text { Karakter pada video motiongraphic Mengenal } \\
\text { Wama Dalam Bahasa Inggris sudah sesuai } \\
\text { untuk anak-anak. }\end{array}$ & & 4 & & & \\
\hline 4. & $\begin{array}{l}\text { Penyampaian suara (dubbing) yang diucapkan } \\
\text { sudah sesuai dan mudah dipahami. }\end{array}$ & 2 & 2 & & & \\
\hline 5. & $\begin{array}{l}\text { Video motion graphic Mengenal Wama Dalam } \\
\text { Bahasa Inggris mudah dimengerti oleh anak- } \\
\text { anak. }\end{array}$ & & 4 & & & \\
\hline 6. & $\begin{array}{l}\text { Video sudah cocok ditayangkan sebagai bahan } \\
\text { ajar untuk anak TK }\end{array}$ & 2 & 2 & & & \\
\hline 7. & $\begin{array}{l}\text { Durasi video sudah sesuai sebagai bahan ajar } \\
\text { untuk anak TK. }\end{array}$ & 1 & 3 & & & \\
\hline 8. & $\begin{array}{l}\text { Video mengandung nilai yang dapat } \\
\text { menambah pengetahuan anak tentang wama } \\
\text { dalam Bahasa Inggris. }\end{array}$ & 2 & 2 & & & \\
\hline 9. & $\begin{array}{l}\text { Secara keseluruhan video sudah cocok untuk } \\
\text { digunakan sebagai bahan ajar untuk anak TK }\end{array}$ & 2 & 1 & 1 & & \\
\hline
\end{tabular}

Berdasarkan data yang diperoleh dari para validator sebagai bagian dari uji alpha, ditemukan hasil dari validasi oleh ahli adalah "Baik" dengan nilai $77 \%$. Selain itu telah dilakukan perbaikan berdasarkan masukan validator yaitu mengubah backsound menjadi lagu anak-anak yang diambil dari Youtube. Dengan pencapaian kategori baik ini, maka dilakukan beta testing kepada subjek penelitian yang sudah ditentukan sebelumnya.

Untuk pengujian beta, dilakukan dengan metode uji pretest dan posttest, dimana hasil pengujian dilihat dari rata-rata nilai pada soal yang telah diberikan. Uji pretest dan posttest dilakukan di TK Islam Ibnu Khaldun selama 2 hari yaitu pada tanggal 5 dan 6 September 2018. Dalam pengujian ini terdapat 10 pertanyaan dan diberikan kepada 18 anak. Pada soal posttest memiliki tingkat kesulitan yang sama seperti soal pretest yang diberikan sebelumnya. Ditemukan 
peningkatan nilia dari semula pretest nilai rata-rata adalah 8.5 sedangkan ketika pemberian posttest ditemukan rata-rata senilai 9.7. Perbedaan nilai tersebut menunjukkan bahwa terdapat peningkatan setelah diberikan posttest. Hasil impelementasi ini membuktikan bahwa bahan ajar dalam bentuk video bermanfaat dengan baik dalam kegiatan belajar mengajar di sekolah karena dapat meningkatkan pemahaman siswa mengenai materi yang sedang dipelajari dan mempermudah guru dalam mengajar dengan mengikuti perkembangan teknologi saat ini.

\subsection{Distribution}

Setelah melakukan tahap testing pada video motion graphic yang telah dibuat, maka tahap berikutnya adalah mendistribusikan video untuk dijadikan bahan ajar bagi guru di TK Islam Ibnu Khaldun. Pemberian video diberikan dalam bentuk DVD yang diserahkan kepada Bapak Kepala Sekolah serta dibagikan juga secara umum di Youtube untuk dapat diakses oleh masyarakat luas.

\section{KESIMPULAN}

Penelitian ini telah dikembangkan dengan mengikuti metode Luther-Sutopo sebagai pengembangan multimedia yang dimulai dari tahapan concept, design, material collecting, assembly, testing dan distribution. Kemudian software yang digunakan selama pembuatan motion graphic adalah Adobe Illustator CS6 dan Adobe After Effect CS6. Hasil akhir dari pembuatan produk adalah video dengan format .mp4 yang berdurasi 05.40 menit dengan menggunakan Adobe Premiere CS6. Video motion graphic ini telah diimplementasikan pada anak TK yakni di TK Islam Ibnu Khaldun. Dimana dengan adanya video motion graphic ini para guru merasa terbantu didalam penyampaian materi kepada para siswa. Untuk pengembangan penelitian berikutnya, sebagai media pembelajaran untuk anak TK, akan lebih bagus lagi jika dikembangkan media pembelajaran berupa nyanyian dan gerakan yang dapat diikuti siswa sehingga lebih menarik untuk digunakan anak usia dini. Sebagai media pembelajaran, lebih dikembangkan lagi bentuk media pembelajaran yang beragam untuk penggunaan teknologi informasi didunia pedidikan.

\section{DAFTAR PUSTAKa}

[1] Fitriyani, N (2014). Pengembangan Aplikasi Pengenalan Huruf, Angka dan Warna Untuk Anak Usia Dini Berbasis Android, Sekolah Tinggi Teknologi Garut.

[2] Hasan, M. (2009). PAUD (Pendidikan Anak Usia Dini). Yogyakarta: Diva Press.

[3] Hernia, Hesti. (2013). Kemampuan Mengenal Warna Pada Anak Usia 4-5 Tahun Di TK Segugus III Kecamatan Panjatan Kabupaten Kulon Progo, 3. Skripsi. Yogyakarta: Universitas Negeri Yograkarta.

[4] Marlin, Andini, Wahyuni. (2012). Aplikasi Pengenalan Dasar-Dasar Bahasa Inggris Untuk Anak Usia Dini Menggunakan Adobe Flash CS3 Professional, Universitas Gunadarma.

[5] Purwanti, Haryanto (2015). Pengembangan Motion Graphic Pembelajaran Mata Pelajaran Pendidikan Kewarganegaraan Kelas I Sekolah Dasar. Fkultas Ilmu Pendidikan UNY.

[6] Sanaky, H. (2009). Media Pembelajaran. Yogyakarta: Safiria Insania Press.

[7] Siroj, B (2010). Pemanfaatan Software Macromedia Flash Sebagai Media Pembelajaran Bahasa Inggris Anak Usia Dini. Universitas Negeri Semarang

[8] Sukiman. (2012). Pengembangan Media Pembelajaran. Yogyakarta: PT. Pustaka Insan Madani.

[9] Suyanto. (2007). Multimedia Alat Untuk Meningkatkan Keunggulan Bersaing. 